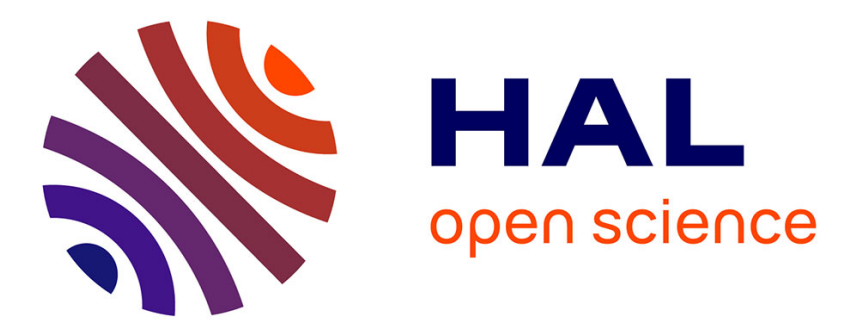

\title{
TOURISM AND GLOBALIZATION: THE INTERNATIONAL DIVISION OF TOURISM PRODUCTION
}

\author{
Jean-Jacques Nowak, Sylvain Petit, Mondher Sahli
}

\section{> To cite this version:}

Jean-Jacques Nowak, Sylvain Petit, Mondher Sahli. TOURISM AND GLOBALIZATION: THE INTERNATIONAL DIVISION OF TOURISM PRODUCTION. Journal of Travel Research, 2010, 49, pp.228 - 245. hal-01831527

\section{HAL Id: hal-01831527 \\ https://hal.science/hal-01831527}

Submitted on 6 Jul 2018

HAL is a multi-disciplinary open access archive for the deposit and dissemination of scientific research documents, whether they are published or not. The documents may come from teaching and research institutions in France or abroad, or from public or private research centers.
L'archive ouverte pluridisciplinaire $\mathbf{H A L}$, est destinée au dépôt et à la diffusion de documents scientifiques de niveau recherche, publiés ou non, émanant des établissements d'enseignement et de recherche français ou étrangers, des laboratoires publics ou privés. 


\title{
TOURISM AND GLOBALIZATION: THE INTERNATIONAL DIVISION OF TOURISM PRODUCTION
}

\author{
Jean-Jacques Nowak \\ EQUIPPE, Université de Lille1. France \\ Sylvain Petit \\ EQUIPPE, Université de Lille1. France \\ Mondher Sahli \\ Victoria University of Wellington. New Zealand
}

(Reference: Nowak J-J., Petit S. \& M. Sahli (2010) «Tourism and

Globalization: The International Division of Tourism

Production», Journal of Travel Research, 49(23):228-245)

Address for correspondence:

Dr Mondher Sahli, Victoria University of Wellington, VMS.

Po Box 600 Wellington - New Zealand. Email : mondher.sahli@vuw.ac.nz 


\title{
TOURISM AND GLOBALIZATION: THE INTERNATIONAL DIVISION OF TOURISM PRODUCTION
}

\begin{abstract}
An important facet of globalization is the international fragmentation of production. This phenomenon, also called international division of production processes, or outsourcing, or vertical specialization... has been studied for goods and many services but has so far been ignored for tourism. In this paper, we attempt to rectify that by providing theoretical and empirical evidence of various aspects of the international division of tourism production (IDTP). In our modeling section we deliberately chose the traditional Ricardian paradigm of international trade theory to explain how the international splittingup of value added chain in the tourism industry can occur across countries. We then conduct an empirical study of a sample of 38 countries to measure their comparative advantages in two segments of the tourism product system. Data over the period 1980-2004 indicates that tourism production is globally fragmented and that the scale of such fragmented production is quite substantial. Furthermore, our long-term dataset shows that tourism specialization is a dynamic process. Using more disaggregated data for $15 \mathrm{EU}$ countries, we found evidence of a high level of fragmented tourism production. The main conclusions of this paper are that trade of tourism segments is the most dynamic component of international tourism trade and that international fragmentation is increasingly taking place, especially within the 15 countries of the pre-2004 Enlargement European Union.
\end{abstract}

Keywords: Tourism specialization, international fragmentation, comparative advantage, international tourism flows, value added chain. 


\section{INTRODUCTION}

One of the most striking features of the recent wave of globalization is the splitting up of the firms' production process into various components which are then produced at different locations around the world (Krugman, 1995; Arndt, 1997a; Yeats, 2001). Goods are thus produced in multiple stages across multiple countries with each country completing some stages of the production sequence and then exporting the good-in-process or the final good to another country. This phenomenon involves trade in intermediate goods (parts and components, semi-finished goods) and has deeply influenced the evolution of international trade over the last few decades (Krugman, 1995; Hummels, Rapoport and Yi, 1998; Yi, 2003). Sometimes called production sharing by the companies involved, it has been alternatively referred to as international division of production processes (LassudrieDuchêne, 1982, 1985), outsourcing (Katz and Murphy, 1992), delocalization (Leamer, 1996), international fragmentation (Jones, 2000; Arndt and Kierzkowski, 2001), vertical specialization (Hummels, Ishii and Yi, 2001) or slicing the value chain (Krugman, 1995).

More precisely, this international division of production takes place in industries in which the production process can be broken down into technologically separate and independent operations providing intermediate inputs to be assembled in the final product. A segment of production is thus defined as the operations which produce a finished good used as an input for the following segment. When the different segments take place in production units located in different countries, we have an international division of the production process (Lassudrie-Duchêne, 1985). 
Although most attention has been paid so far to the case of goods (cars, electronics, chemical products...), evidence suggests that many services tend to be internationally fragmented ${ }^{\mathrm{i}}$, as well. The existing work in this field suggests that differences in factors' prices, investment liberalization and reduced communication and transport costs are among the main driving forces behind the tendency for increased fragmentation in service sectors. Service sectors that are likely to be internationally segmented will tend to have multiple, sequential segments of production, analogous to motor vehicles or electronics, with different countries producing different segments in the sequence. For example, in the case of the U.S., Chen, Kondratowicz and Yi (2005) identify affiliated services, financial services, and business, professional, and technical services as vertically specialized. For these sectors, they constructed a vertically specialized chain of production, making appropriate assumptions about the length of the chain (number of stages), the geographic sequence of the chain (the countries that the production chain goes through) and the value added at each stage of production. Forrester Research (2002) describes nine services occupation categories subject to potential outsourcing, which combined represent 44 per cent of total US employment in 2002. According to several surveys by international organizations (UNCTAD, 2004; OECD, 2005; WTO, 2005), the most commonly outsourced activities are IT-enabled "Business Processing Outsourcing" services, including call centre support and other back-end business process operations such as data entry and handling, coding, medical and legal transcriptions and testing. International fragmentation is also increasingly implemented in higher end activities, or "Knowledge Process Outsourcing", which include valuation and investment analysis, market research, consulting, software design, legal and insurance claims processing, architecture, drafting and filing of patent applications, drug discovery and other types of R\&D activities, chip design and embedded systems, analytics and inventory management. 
Despite this extensive list of service activities that are already internationally fragmented or potentially exposed to international trade, tourism services have so far been ignored by trade economists and tourism scholars. This is perhaps due to the fact that the common representation of tourism is largely dominated by a package of 'on premises' services which offer a particular lifestyle and ambience for tourists while they are at the destination (accommodation services, food and drink services, entertainment, local excursions and sightseeing tours, etc). Tourism is often perceived as a single stage activity. However, the tourism product is not a single product but an amalgam (Burkart and Medlik, 1974; Dunning and McQueen, 1981; Gilbert, 1990). It is made up of highly heterogeneous activities that are combined in multiple sequential stages. For example, according to the tourism satellite account (TSA) document (Eurostat/OECD/WTO/UN, 2001), tourism characteristic activities include 12 sectors $^{\text {ii. }}$ Sinclair and Stabler (1997, p.58) define the tourism product as a "composite product involving transport, accommodation, catering, natural resources, entertainment, and other facilities and services, such as shops and banks, travel agents, and tour operators."iii All these components are technologically separate and independent, and sequentially linked into a value added chain whose final product is the tourism product itself. This is particularly important when we examine a tourism product sold by a packager (tour-operator) which elaborates it and sells it directly or through travel agencies to a traveller. The latter receives a combination of products associated to a trip, which are made of more than one of the tourism services mentioned above.

In this paper, we consider the activity of the packager as that of assembling the components of a package, in order to create a totally new product, in the same way as a carmaker assembles the different parts of a vehicle to 'produce' a final product, which is 
considered as different from the sum of its components and provides a different satisfaction and service to the consumer than the sum of its parts. In our case, the different goods and services put together by the packager in order to make up the "package tour" are considered as intermediate consumption of the activity of the tourism intermediary. Therefore, it seems quite justified to consider the package tour sold by the tour-operator as an aggregated product or a "product-system" which can be broken down into many segments of production. But all these segments can be very different from each other as they require different technologies, different factors of production (labour, capital, natural resources, infrastructure) combined in different proportions, different skills for human resources, different content in informational or marketing inputs... For example, the passenger transportation sector is very capital intensive as compared to entertainment or accommodation, which are traditionally viewed as labour-intensive activities because of their highly personal service nature. Nevertheless the latter also require large amounts of space (in the form of beaches, scenery, forests, mountains, etc) which can make them rather land intensive (Nowak and Sahli, 2007). Transport services and tour operating often use the more modern and up-to-date technologies, especially information and communication technologies (ICTs), such as CRSs, GDSs, DMSs, ..., whereas catering and entertainment can still rely on more traditional, standardized and sometimes outdated technologies. However some sub-segments of entertainment can rely on high technology as well as, for example, technology-oriented adventure parks.

Considering thus the large diversity in the conditions of production of the tourism product's segments or sub-segments and given that nowadays most of them can be exported and imported ${ }^{\text {iv }}$, it seems highly unrealistic that each country could be competitive for all of them and could specialize in the whole "product-system". It seems more reasonable to 
assume that tourism's value added chain will be internationally split up by private firms across different countries according to varying factors. These include, for example, countries' respective technological levels and their endowments in skilled or unskilled labour, in capital, in man-made and natural attractions. Therefore, a country may have a comparative advantage in one segment of the production process and a disadvantage in another segment. If segments do indeed take place in production units located in different countries, we would then be in the presence of an international division of tourism production (IDTP) $)^{\mathrm{v}}$.

To the best of our knowledge, all studies on tourism specialization (see for example Peterson, 1988; Jensen and Zhang, 2006; Algieri, 2006) have only focused on one particular segment of the product-system, namely the services provided to international inbound visitors by the destination country (accommodation, food and drink, local excursions and sightseeing tours, cultural and sporting events, other entertainment, etc. $)^{\mathrm{vi}}$. Unlike previous studies, we claim that any assessment of a country's specialization in tourism should be based on the concept of a tourism product-system and should explicitly investigate the possibility of comparative advantages in other segments of the value added chain in the tourism industry. The specific contribution of this paper is to consider tourism specialization in terms of international fragmentation.

The paper is structured as follows. The next section provides a simple theoretical background for our empirical investigation of international travel trade. Section three discusses the data set and describes the indicators used to assess IDTP. Section four is devoted to the empirical analysis of IDTP in two countries' samples. The paper ends with concluding remarks. 


\section{RELEVANT THEORY}

The first theoretical studies of international fragmentation appeared in the early 1980s. Sanyal and Jones (1982) and Ethier (1982) developed models of trade in intermediate inputs. Dixit and Grossman (1982) and Sanyal (1983) applied comparative advantage to vertical stages of production between countries. Lassudrie-Duchêne (1982, 1985), Berthélemy et al. (1986) and Fontagné (1991) provided trade models in which goods are produced in distinct stages of production that can be geographically fragmented. Plenty of theoretical models are thus available today that account for fragmentation and its importance in the global economy, including more recent works such as Deardorff (2001, 2005), Grossman and Helpman (2002a, 2002b, 2005), Jones and Kierzkowski (2005), Venables (1999), Yi (2003) and Markusen (2005), just to cite a few.

One of the most noteworthy results of all these models is that over and above the traditional gains from increased specialization and exchange across countries, trade in intermediate inputs and fragmentation bring additional efficiency gains that amount to an outward shift in the production frontier for final goods in each country.

As tourism is mostly a service activity and many of the models cited above deal with fragmentation in services, there is no reason to think they could not be applied to the case of the tourism "product-system." Thus their conclusions should be valid when considering international tourism. Developing a new theoretical model is beyond the scope of this paper. Instead we propose some simple theoretical insights to better understand how and why international fragmentation is relevant for tourism services. 
As already stated in the previous section, it is appropriate to view tourism activity as a "product-system" that is made up of a combination of services and goods ranging from transportation to sightseeing. Taking the Eurostat/OECD/WTO/UN classification (2001) as a basis, five main segments can be distinguished:

- the attraction/entertainment sector, which comprises man-made and natural attractions which are developed to satisfy visitors' educational, recreational, aesthetic needs: museums, wildlife parks, entertainment, theme parks...

- the accommodation sector, that is all types of establishments that offer lodging to visitors: hotels, bed and breakfast, campsites...

- the transport sector which includes air, water and surface transport: airlines, railways, car rental operators...

- the travel organizer sector: tour operators, travel agents...

- the destination organization sector (national/local tourist offices, tourism association...).

To simplify matters, we have grouped together some of these segments in order to consider only three main components, namely intermediaries (travel agents and tour operators) (I), passenger transportation services ( $\mathrm{T}$ ) and accommodation-cateringentertainment $(\mathrm{A})^{\mathrm{vii}}$.

However this official classification is incomplete as the production of each component needs goods and services as inputs: food, beverages, furniture, laundering, accounting, management..., including all kinds of tourist equipment like outdoor clothing, sunglasses, tents, etc. These goods and services are either bought from domestic suppliers 
or are imported. In any case, they must be considered as intermediate inputs and as additional segments of production.

To sum up, consider the simple case of an all-inclusive pre-paid package tour (called V). This aggregated (final) tourism product can be seen as the result of a sequential production process involving three stages: upstream, middle and downstream stages (see Figure 1).

[Please insert Figure 1 here]

The upstream stage consists of the goods and services just pointed up above that enter into the production function of components I, T and $\mathrm{A}$ as intermediate inputs. The middle stage is made up of accommodation-catering-entertainment services (component A) and passenger transportation services (component $\mathrm{T}$ ). These services are in turn intermediate inputs for the downstream stage, i.e. the assembling and marketing operations completed by intermediaries in the distribution channels, such as tour operators and/or travel agencies (component I) ${ }^{\text {viii. }}$. Their role is to package components $\mathrm{A}$ and $\mathrm{T}$ into a single aggregated tourism product (V) that will be sold as an identified pre-established unit.

Note that at each stage, segments are internationally tradable, i.e. may be exported or imported by the country. Tradability for services is more recent than for goods and results to a large extent from the impressive development of new information and communication technologies, from the progressive liberalization of foreign direct investment all over the world and from the emergence of new forms of international investment. Tourism is not an exception to the rule. Usually, the narrow and restrictive definition of tourism (as made up of segment A only) leads to the inclusion of its 
transactions in mode 2 of the World Trade Organization's typology (consumption abroad). But when considering its other segments, all four modes of supply for trade in services defined by the World Trade Organization are involved. In particular, the development of the Internet now allows cross-border transactions (mode 1) for segments T, I and for the upstream stage. For instance, GDSs display routes and fares for tour operators and travel agents of different countries who book flights and also carry information on hotels, car rentals and other tourist-related services from all over the world. When a travel agent in Australia uses the Sabre reservation system (owned by AMR, the parent of American Airlines) to book a passenger flight on Qantas, Qantas pays a fee to Sabre, and thus to AMR. This fee is considered as an import in the Australian balance of payments.

But for each segment, exports and imports of services can also be achieved through the presence of commercial affiliates, thus involving foreign direct investment (mode 3 of trade in services according to the World Trade Organisation typology). In this case, services for an import country are provided by a locally-established affiliate, subsidiary or representative office of a foreign-owned company. On the basis of the data available on tourism foreign direct investment, the use of non-equity forms (leasing agreement, management contract, franchise agreement or some marketing agreements) seems more common than equity forms (major or minor equity and joint venture) ${ }^{\mathrm{ix}}$.

While all segments are thus potentially tradable from a technical point of view, only economic mechanisms make them become really traded (i.e. exported or imported). The rest of this section is devoted to the presentation of some of these mechanisms which can finally be the cause of the international fragmentation of tourism production. 
Let us first notice that for all segments, local production needs a wide range of primary factors of production (labour of different skills, capital, natural resources, infrastructure) and require some level of different technologies. They also probably involve significant transaction costs (e.g. search and information) and fixed costs (e.g. in the air transport) (Sinclair and Stabler, 1997). Thus the more relevant theoretical approach to deal with IDTP is to mix up some principles from the Ricardian theory of comparative advantage with the ones of the Heckscher-Ohlin framework, or even to use the "new" international trade theories (neo-technological and imperfect competition models; Helpman and Krugman, 1985). However, to keep the matter uncomplicated and for the purpose of illustration only, we use the simplest theoretical framework of international trade, namely the Ricardian model to describe a fairly general formulation of the concept of IDTP ${ }^{\mathrm{x}}$.

We consider a two-country world (X and $\mathrm{Y}$ ) and many goods, satisfying the usual assumptions of a Ricardian framework (constant returns to scale technology, competitive markets, price flexibility...). We suppose that there are two final goods, the tourism product $(\mathrm{V})$ and the manufacturing good $(\mathrm{M})$. Labour is the only direct factor of production and can freely move in the economy.

We also assume that the process for producing one unit of aggregated tourism product $(\mathrm{V})$ can be split into multiple parts that are internationally tradable. For simplicity, we consider here that production of $\mathrm{V}$ is fragmented into just three parts: component $\mathrm{A}$ (accommodation-catering-entertainment), component $\mathrm{T}$ (transport of passengers) and component I (intermediaries) ${ }^{\mathrm{xi}}$. These components are linked in the manner described in Figure 1. The process of production is then as follows. Segments A and T are produced using labour only. They are combined with segment I which also uses labour to produce the 
aggregated tourism product V. Finally, the manufacturing sector only uses labour in producing the good $\mathrm{M}$.

Let $a_{L j}^{i}$ be the amount of labour needed in country i to produce one unit of good or service $\mathrm{j}$, with $\mathrm{i}=\mathrm{X}, \mathrm{Y}$ and $\mathrm{j}=\mathrm{M}, \mathrm{A}, \mathrm{T}, \mathrm{I}$. Because of constant returns to scale, this coefficient is constant. It depends on the country's level of technological development for $\mathrm{j}$ only. The inverse of this coefficient $\left(1 / a_{L j}^{i}\right)$ represents the marginal (or average) product of labour in the $\mathrm{j}$ sector or segment and is denoted by $\pi_{L j}^{i}$. Let us also assume that the intermediate input coefficients of $\mathrm{V}$ (amounts of $\mathrm{A}$ or $\mathrm{T}$ required to produce one unit of $\mathrm{V}$ ) are fixed and the same for both countries. Lastly, consider that international trade is free. Then following Jones (1961) and Deardorff (2005), comparative advantages can be defined in terms of the sectors' unit labour requirements only (or equivalently, labour

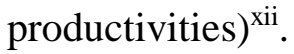

Firstly, we express the technology gap between the two countries for any j sector as the ratio of their respective labour requirements or, equivalently, by the ratio of their marginal products of labour: $a_{L j}^{Y} / a_{L j}^{X}=\pi_{L j}^{X} / \pi_{L j}^{Y}$. Secondly, these technology gaps have to be ranked in order to determine the chain of comparative advantages between country $\mathrm{X}$ and Y (Haberler, 1936; Dornbusch et al., 1977). Three tourism segments and one (final) manufacturing sector give $4 !=24$ possibilities. Examining only one case would be sufficient to reveal the possibility of an IDTP. We assume for example the following ranking:

$$
\frac{a_{L A}^{Y}}{a_{L A}^{X}}<\frac{a_{L I}^{Y}}{a_{L I}^{X}}<\frac{a_{L T}^{Y}}{a_{L T}^{X}}<\frac{a_{L M}^{Y}}{a_{L M}^{X}}
$$

Or, as equivalent: 


$$
\frac{\pi_{L A}^{X}}{\pi_{L A}^{Y}}<\frac{\pi_{L I}^{X}}{\pi_{L I}^{Y}}<\frac{\pi_{L T}^{X}}{\pi_{L T}^{Y}}<\frac{\pi_{L M}^{X}}{\pi_{L M}^{Y}}
$$

This inequality tells us that the manufactured (final) good $\mathrm{M}$ is the most efficient (or the least inefficient) production for country $\mathrm{X}$ with respect to country $\mathrm{Y}$; then it is segment $\mathrm{T}$, then segment I. Component $\mathrm{A}$ is the least efficient production (or the most inefficient production). From this, it follows that $\mathrm{X}$ displays its largest comparative advantage for good $\mathrm{M}$, then for segment $\mathrm{T}$ followed by segment $\mathrm{I}$, and its largest comparative disadvantage for segment A, then for segment I, etc. The opposite reasoning is valid for country Y.

Finally, to determine the dividing line between goods exported and goods imported by each country, i.e. the pattern of specialization, this chain of comparative advantages must be cut by the ratio of the two countries' wage rates: $w^{X} /\left(w^{Y} \cdot e\right)$, where $w^{X}$ denotes the wage rate in country $\mathrm{X}, w^{Y}$ the wage rate in country $\mathrm{Y}$ (in local currency) and e the exchange rate ( 1 unit of Y's currency $=e$ units of X's currency $)^{\mathrm{xiii}}$.

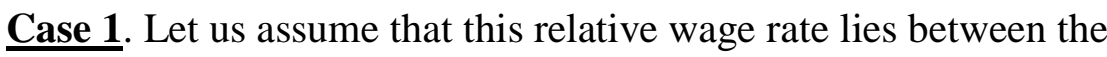
international technology gaps for segment $\mathrm{T}$ and (final) good $\mathrm{M}$ :

$$
\frac{a_{L A}^{Y}}{a_{L A}^{X}}<\frac{a_{L I}^{Y}}{a_{L I}^{X}}<\frac{a_{L T}^{Y}}{a_{L T}^{X}}<\frac{w^{X}}{e \cdot w^{Y}}<\frac{a_{L M}^{Y}}{a_{L M}^{X}}
$$

Following assumption (2), $\mathrm{X}$ specializes in good $\mathrm{M}$ and $\mathrm{Y}$ specializes in segments I, $\mathrm{T}$ and $\mathrm{A}^{\mathrm{xiv}}$. Country Y displays a comparative advantage for all tourism segments while country $\mathrm{X}$ displays a comparative disadvantage for all of them. This case depicts the situation where $\mathrm{Y}$ is a host country selling integrated package tours to tourists from country $\mathrm{X}$. 
Equivalently, this chain of comparative advantage shows that $\mathrm{X}$ is a tourism origin country whose residents spend their holidays in country Y using this country's TO and transport companies to travel.

Consequently, country $\mathrm{Y}$ is able to produce the whole final tourism product system (V) and trades it for the manufactured good M. X will export the manufactured good M and import the aggregated tourism product $\mathrm{V}$. There is no trade in tourism segments here and no international division of tourism production process. International trade is made up of exchanges of final products only ( $\mathrm{V}$ for $\mathrm{M})$.

Case 2. Let us assume now that the relative wage rate lies between the international technology gaps for segment I and segment T:

$$
\frac{a_{L A}^{Y}}{a_{L A}^{X}}<\frac{a_{L I}^{Y}}{a_{L I}^{X}}<\frac{w^{X}}{e \cdot w^{Y}}<\frac{a_{L T}^{Y}}{a_{L T}^{X}}<\frac{a_{L M}^{Y}}{a_{L M}^{X}}
$$

The production of segments A and I is still more expensive in country $\mathrm{X}$ than $\mathrm{Y}$, but now the production cost of segment $\mathrm{T}$ is lower in $\mathrm{X}$ than $\mathrm{Y}^{\mathrm{xv}}$. Therefore country $\mathrm{X}$ specializes in $\mathrm{T}$ and $\mathrm{M}$ while country $\mathrm{Y}$ specializes in segments $\mathrm{A}$ and $\mathrm{I}$ ( $\mathrm{Y}$ is then still the host country whereas $\mathrm{X}$ is still the tourism origin economy). In other words, $\mathrm{X}$ will export passenger transport services (segment T) and the manufactured good M to TOs and residents from country $\mathrm{Y}$, and will import the package tours $\mathrm{V}^{\mathrm{xvi}}$.

Country Y's packagers (tour operators) assemble accommodation services, food serving services and entertainment services provided by firms within their own economic territory with passenger transport services imported from $\mathrm{X}$ to make up all-inclusive 
package tours $\mathrm{V}$. This aggregated tourism product is then exported to country $\mathrm{X}^{\mathrm{xvii}}$ and sold to country Y's domestic travellers as well.

Nevertheless, it is important to mention that country Y's true (net) exports are only made of segments A and I included in V. The value of transport services embodied in $\mathrm{V}$ has not been produced by country Y, but previously purchased and imported from country $\mathrm{X}$ and can be seen as a kind of re-exportation by country $\mathrm{Y}$. Using terminology of international trade (e.g. EU Customs), these imports of transport services by country Y from country X should be called inward processing imports ${ }^{\mathrm{xviii}}$ as they are further processed at home and embodied in a more elaborated export good.

Conversely, as these services have been sold to country Y's packagers by country X's passenger transport companies before being included in the package tour, they must be counted as exports for country X (even if they are used by their own residents). Using the terminology of international trade, these exports by country X to country Y should be called outward processing exports ${ }^{\mathrm{xix}}$ as they are exported to be further processed overseas. While country X imports the aggregated package tours V, its true (net) imports are only made of segments A and I included in V. (See Figure 2.)

[Please insert Figure 2 here]

Unlike in case 1, country Y does not export anymore all the components of the package tour. The value added chain in tourism has thus been split up. The tourism activity has been internationally fragmented and the delocalization of segment $T$ to country $X$ has given rise to an IDTP. 
Another point deserves mention. According to the chain of comparative advantage (3), all passenger transport services are produced by country X. Therefore country X's carriers are used by country Y not only to carry foreign tourists but also to transport its own residents for domestic travel. In other words, residents of country Y use country X's carriers to travel within their own country. This case is usually referred to as "cabotage". The European Union provides a good illustration of this concept of cabotage in the airline sector. It is nowadays a single market in air transport, and any airline registered within the Union is able to offer commercial services within any other part of the Union, whether between member countries or within an individual country ${ }^{\mathrm{xx}}$. The liberalization of air transport in Europe can then be thought of as a catalyst of international fragmentation in the European tourism industry.

To sum up, cases 1 and 2 show that two different types of tourism specialization could be distinguished. If a country displays comparative advantages in all stages of production of the tourism product, from upstream to downstream production (case 1), this country is said to have an (positive) "integrated" tourism specialisation: it produces and exports the aggregated tourism product. Note that, if this country has comparative disadvantages in all stages of the tourism production process, it has to import the whole tourism product-system, and we are still in a situation of an "integrated" tourism specialization (referred to as negative "integrated" tourism specialization).

If comparative advantages can be found in some stages of production only (case 2), we are in the presence of "partial" tourism specialisation. Countries are specialized in different segments of the tourism product system. An international trade in tourism segments arises from this IDTP. 
Let us end this section by noting that, although this framework appears rather simple, it turns out to be very fruitful. It enables us to consider a wide range of different situations, either current or to come. Consider for example the following ranking of comparative advantages:

$$
\frac{a_{L A}^{Y}}{a_{L A}^{X}}<\frac{a_{L T}^{Y}}{a_{L T}^{X}}<\frac{w^{X}}{e \cdot w^{Y}}<\frac{a_{L I}^{Y}}{a_{L I}^{X}}<\frac{a_{L M}^{Y}}{a_{L M}^{X}}
$$

Country X has a comparative advantage for good $\mathrm{M}$ and segment I whereas $\mathrm{Y}$ has a comparative advantage for segments $\mathrm{A}$ and $\mathrm{T}$. This new chain of comparative advantage suggests that country X's packagers organize all-inclusive package tours V to tourists of both countries. These tours are organized by assembling imported A and T services from country Y (i.e non-domestically produced components of the package). This latter is still the receiving country and transports tourists with its own carriers (like in case 1 but unlike in case 2). However, its residents now spend their holidays in their own country by buying an all-inclusive tour from country X's packagers. While sales of intermediaries' services to residents of other countries have not been very common in tourism, these practices are currently expanding in the European holiday market where large integrated tour operators dominate tourism distribution channels via an integration, consolidation and concentration phenomenon (Koutoulas, 2006). Additionally, the impact of information communication technologies (ICTs), such as the World Wide Web and e-tourism have changed the nature of tourism distribution channels. The case of fragmentation just described is then likely to become more and more frequent.

Moreover, it corresponds to the concept of vertical specialization as defined by Hummels, Ishii and Yi (2001). This concept appears narrower than the concept of international fragmentation but seems very powerful to explain some recent puzzles in 
international trade in goods (see for example Yi, 2003; Chen, Kondratowicz and Yi, 2005). According to these authors, vertical specialization occurs when 1) goods are produced in multiple, sequential stages; 2) two or more countries provide value-added in the good's production sequence; 3) at least one country must use imported inputs in its stage of the production process, and some of the resulting output must be exported. The case described by the chain (4) fits all these criteria as country $\mathrm{Y}$ uses intermediate inputs from country $\mathrm{X}$ (segments $\mathrm{A}$ and $\mathrm{T}$ services) and exports the resulting output (package $\mathrm{V}$ ) back to $\mathrm{it}^{\mathrm{xxi}}$. Another important case of vertical specialization in tourism may arise if the upstream stage of the tourism production process (see Figure 1) is taken into account in the analysis. A vertically specialized production chain emerges if part of the goods and services used as inputs by segments A, T and I are imported, and if these segments are in turn exported.

\section{METHODS}

The detection of any IDTP requires the measure of comparative advantages for the different components of the tourism product system and for different countries. Several ways have been suggested in the international trade literature to empirically represent the overall pattern of comparative advantages and disadvantages of a national economy. In this paper, we chose mainly the "contribution to the trade balance" indicator that has been developed by the "Centre d'Etudes Prospectives et d'Informations Internationales" (CEPII), the leading French think tank specialized in international economics, to have an understanding of a country's position in the IDTP ${ }^{\text {xxii }}$.

For a given country, this index gives the contribution of any sector to the overall trade balance. It can be interpreted as an indicator of comparative advantage since it 
indicates whether a sector performs relatively better or worse than the whole economy, whether the whole economy itself is in deficit or surplus. Unlike many other indicators, it is a symmetrical indicator in the sense that it takes into account not only exports, but both exports and imports. It also eliminates business cycle related effects such as the impact on trade of changes in the real exchange rate.

The "contribution to the trade balance" of sector $\mathrm{i}$ is the difference between the actual net balance of sector $\mathrm{i}$ and the theoretical net balance of $\mathrm{i}$. The theoretical net balance corresponds to the net value that the sector i would register if global equilibrium occurred in the country's trade. More precisely, if there were no comparative advantage or disadvantage for any sector, then a country's total trade balance (surplus or deficit) would be distributed across all sectors according to their share in total trade. The result gives us the theoretical net balance of each sector.

Expressed in thousands of GDP (to allow comparisons across sectors), the contribution to trade balance of sector $\mathrm{i}$ in country $\mathrm{j}$ for year $\mathrm{t}$ is defined as ${ }^{\mathrm{xxiii}}$ :

$$
\operatorname{CTB}_{\mathrm{ij}}^{\mathrm{t}}=\frac{1000}{\operatorname{GDP}_{\mathrm{j}}^{\mathrm{t}}} \cdot\left[\left(\mathbf{X}_{\mathrm{ij}}^{\mathrm{t}}-\mathbf{M}_{\mathrm{ij}}^{\mathrm{t}}\right)-\left(\frac{\mathbf{X}_{\mathrm{ij}}^{\mathrm{t}}+\mathbf{M}_{\mathrm{ij}}^{\mathrm{t}}}{\mathbf{X}_{. \mathrm{j}}^{\mathrm{t}}+\mathbf{M}_{. \mathrm{j}}^{\mathrm{t}}} \cdot\left(\mathbf{X}_{. \mathrm{j}}^{\mathrm{t}}-\mathbf{M}_{. \mathrm{j}}^{\mathrm{t}}\right)\right)\right]
$$

with:

$\mathbf{X}_{. \mathbf{j}}^{\mathrm{t}}$ and $\mathbf{M}_{. \mathbf{j}}^{\mathrm{t}}$ respectively country $\mathrm{j}$ total exports and imports in year $\mathrm{t}$;

$\mathbf{X}_{\mathrm{ij}}^{\mathrm{t}}$ and $\mathbf{M}_{\mathrm{ij}}^{\mathrm{t}}$ respectively country $\mathrm{j}$ total exports and imports of products belonging to sector $\mathrm{i}$ in year $\mathrm{t}$;

$\mathbf{X}_{\mathrm{ij}}^{\mathrm{t}}-\mathbf{M}_{\mathrm{ij}}^{\mathrm{t}}$ the actual (observed) net balance of country $\mathrm{j}$ for sector $\mathrm{i}$ in year $\mathrm{t}$; $\frac{\mathbf{X}_{\mathrm{ij}}^{\mathrm{t}}+\mathbf{M}_{\mathrm{ij}}^{\mathrm{t}}}{\mathbf{X}_{. \mathrm{j}}^{\mathrm{t}}+\mathbf{M}_{. \mathrm{j}}^{\mathbf{t}}}$ the weight of sector i in country $\mathrm{j}$ total trade in year $\mathrm{t}$; 
$\left(\frac{\mathbf{X}_{\mathrm{ij}}^{\mathrm{t}}+\mathbf{M}_{\mathrm{ij}}^{\mathrm{t}}}{\mathbf{X}_{. \mathrm{j}}^{\mathrm{t}}+\mathbf{M}_{. \mathrm{j}}^{\mathrm{t}}}\right) \cdot\left(\mathbf{X}_{. \mathrm{j}}^{\mathrm{t}}-\mathbf{M}_{. \mathrm{j}}^{\mathrm{t}}\right)$ the theoretical net balance of sector $\mathrm{i}$ in country $\mathrm{j}$ in year $\mathrm{t} ;$ GDP $_{\mathbf{j}}^{\mathbf{t}}$ the GDP of country $\mathrm{j}$ in year $\mathrm{t}$.

A positive value for this index $\left(\mathbf{C T B}_{\mathrm{ij}}^{\mathbf{t}}>0\right)$ indicates a structural surplus for sector $\mathrm{i}$ in country $\mathrm{j}$ in year t. Country $\mathrm{j}$ is then said to display a "revealed comparative advantage" for sector i. A negative value $\left(\mathbf{C T B}_{\mathrm{ij}}^{\mathrm{t}}<0\right)$ indicates a structural deficit for sector $\mathrm{i}$; country $\mathrm{j}$ is then said to display a "revealed comparative disadvantage" for sector $\mathrm{i}$ in year $\mathrm{t}^{\mathrm{xxiv}}$.

In conformity with our Ricardian reasoning presented above, this index should be ideally calculated for all segments of the three-stage sequential production process of the tourism product system (described in the previous section; see figure 1) and for a large sample of countries. According to the theoretical section, if the computed $\mathbf{C T B}_{\mathbf{i j}}^{\mathbf{t}}$ has the same sign for all tourism segments i (or alternatively, if $\mathbf{R C A}_{\mathrm{ij}}^{\mathrm{t}}$ is either always above 1 or always below 1), then we conclude that country $\mathrm{j}$ has an "integrated" specialization in tourism: this country exports or imports the aggregated tourism product and is not concerned by any IDTP. But if one $\mathbf{C T B}_{\mathrm{ij}}^{\mathrm{t}}$ at least has a different sign from the others, then we conclude that country $\mathrm{j}$ has a "partial" specialization. It simultaneously exports and imports different tourism segments and is thus involved in an IDTP.

Unfortunately the lack of statistical data at the international level for some segments of the tourism product system prevents us from studying the whole value added chain in tourism $^{\mathrm{xxv}}$. The only reliable tourism services data available are provided by "Travel" and "Transport of passengers" items of each country's balance of payment. As the "Travel" 
item covers primarily the goods and services acquired from an economy by travellers, it can reasonably be considered as a good proxy for segment A (accommodation-cateringentertainment services). On the other hand, the "Transport of passengers" item covers international carriage of travellers, which corresponds to segment $\mathrm{T}^{\mathrm{xxvi}}$. For each of these segments, the indexes CTB and RCA were computed by using trade in all goods and services as reference $\left(\mathbf{X}_{. j}^{t}\right.$ and $\mathbf{M}_{. j}^{t}$ for $\mathbf{C} \mathbf{T} B_{i j}^{t}, \mathbf{X}_{. j}^{t}$ and $\mathbf{X}_{. .}^{t}$ for $\left.\operatorname{RCA}_{i j}^{t}\right)$.

Consequently, in evaluating each country's comparative advantage in segments A and $\mathrm{T}$, we assume that we are able to determine the segments in which each economy is more (or less) efficient than other countries. For instance, if the empirical analysis reveals that $C T B_{A X}^{t}$ (or $R C A_{A X}^{t}$ ) is higher than $C T B_{A Y}^{t}\left(\right.$ or $R C A_{A Y}^{t}$ ) for the same year t, then we can assume that country $\mathrm{X}$ is preferred to country $\mathrm{Y}$ as a place to visit. Therefore, consumers of segment A are supposed to have decided that accommodation-catering-entertainment services in country $\mathrm{X}$ are more attractive than the corresponding one for country $\mathrm{Y}$ (due to the fact that $\mathrm{X}$ produces segment A more efficiently than $\mathrm{Y}$ and/or possesses superior endowments of certain factors, such as climate or scenery).

\section{EMPIRICAL RESULTS}

We apply the methodology discussed above to investigate, at two different geographic aggregation levels, patterns of international fragmentation of tourism production. At the more aggregated level (sub-section IV-1), we calculated the indexes CTB and RCA for segments A and T of each country belonging to a large sample (comprised of 38 developed and developing countries) by considering its trade with all its partners simultaneously ("the rest of the world"). At the less aggregated level (sub-section 
IV-2) the same indexes were computed for each country of a smaller sample (the $15 \mathrm{EU}$ member states) by considering its trade flows on a bilateral basis, i.e. with each of its partner separately. The reason behind this second approach will be explained below.

\section{IV-1. Analysis of multilateral flows.}

In this sub-section, comparative advantages and disadvantages of each country $\mathrm{j}$ for segments A and T were calculated by considering its trade in "Travel" and "Transport passenger" services with the rest of the world (i.e. with all its partners altogether) over a 25 year period spanning 1980-2004. The analysis has been carried out on data for a sample of 38 countries (of which 22 are developed countries and 16 emerging or Less Developed Countries). All data come from the CHELEM database of CEPII (2006).

Let us start by examining the importance of IDTP in terms of countries involved. Tables 1A and 1B describe the evolution of segments A and T's CTB indexes for each country over the 25 years studied. These indexes have been computed for periods of three years in order to provide a more overall picture of the nature, trends and patterns of fragmentation in tourism and eliminate short-term fluctuations.

[Please insert Tables 1A and 1B here]

Several lessons can be drawn from these tables ${ }^{\mathrm{xxvii}}$.

- Firstly, it shows that only 11 countries (out of 38) remained exclusively involved in (negative/positive) integrated tourism specialization over the entire period, either displaying comparative disadvantages for both segments and hence importing the 
whole tourism product system (Brazil, Canada, Denmark, Finland, Germany, Iceland, Japan, Madagascar, Belgium-Luxembourg, UK), or displaying comparative advantages for both segments and hence exporting the whole tourism system (Egypt, although its comparative advantage for segment $\mathrm{T}$ steadily declined since the 1980s until becoming negative in 2004). These countries accounted for about $29 \%$ of the sample, which means that $71 \%$ of all reported countries (i.e. 27 out of 38) had been involved at least once in an IDTP.

Among these 27 countries, seven were permanently involved in the IDTP (Bahamas, Cyprus, France, Malta, Morocco, Senegal, Thailand) while for six other countries, it represented a very dominant, though not exclusive, form of specialization: USA, South Africa, Tunisia, Israel, Italy and Mainland China. (Note that the three last countries tend to move slowly to a net importer integrated specialization due to the progressive erosion of their comparative advantages in segment A.) Four other countries had recourse to international fragmentation only occasionally (the Seychelles and Panama which usually export the whole product system; Norway and Chile which by contrast usually import it). To sum up, the total share of countries for which IDTP was the dominant form of specialization over the 25 years studied accounted for $50 \%$ of the sample.

- Secondly, tourism specialization is not a static phenomenon but a dynamic process evolving over time. More than a quarter of the sample (26.3\%) experienced lasting shifts in specialization, switching from one form to the other.

- Five countries moved from an integrated to a partial specialization. One of them, i.e. Spain, initially had structural surpluses in both segments but opted 
to take advantage of the IDTP by withdrawing from passenger transport services. Others switched from structural deficits in both segments to structural surpluses in one segment (Australia, Malaysia and Mexico in segment A; Netherlands in segment T). These observations demonstrate that in tourism, comparative advantages and disadvantages are not necessarily due to fate but can be the result of a building process.

- Five countries moved in the opposite direction, i.e. from a partial to an integrated specialization. Greece withdrew from the IDTP by specializing in transport services for which it previously recorded a structural deficit. It has now become a net exporter of the whole tourism product system. On the contrary, the four other countries went out of the IDTP by releasing a previously structural surplus segment (Ireland and Switzerland in A, Sweden in T, South Korea for both segments alternately) and now have to import the whole tourism product.

Note that individual evolutions can be quite complex. This was the case for at least two countries of the sample, i.e. Greece and South Korea. Greece was first a structural net exporter of both segments, and chose to be involved in the IDTP for 15 years, before returning to the same integrated specialization. South Korea experienced all forms of specialization: partial with a comparative advantage for each segment alternately, integrated with two comparative advantages, integrated with two comparative disadvantages.

All these shifts in comparative advantage or comparative disadvantage (despecialisation from a segment, upwards movement in the tourism industry, 
reinforcement of upstream or downstream specialization etc.) confirm the dynamic nature of international tourism specialization. Additionally, they provide evidence that some countries were relatively successful in building new comparative advantages within the tourism industry.

Let us now look at the frequency of IDTP cases observed over the entire period. As shown in Table 2, the proportion of cases of partial specialization (i.e a comparative advantage in one segment only) represented an average of $46 \%$ over 1980-2004. In other terms almost half the countries in the sample did not import or export the whole tourism product system over the period and had to import a segment complementary to the segment they produced and exported. This high proportion of observed cases of tourism segments exchange clearly shows the existence of a large-scale splitting-up of tourism's value-added chain at the international level and hence of an IDTP ${ }^{\text {xxviii }}$. Moreover Table 2 and Figure 3 indicate that this IDTP is not really a recent phenomenon since its share was already high in the early 1980s (up to 40\%). After a sharp rise throughout most of the 1990s, this share dramatically fell from 1998 to 2001, but in total it remained at a high level during the last 25 years, fluctuating between $36 \%$ and $55 \%$. In contrast, the case of comparative advantages in both tourism segments has been the least prevalent in international tourism. It represents only an average of $11.2 \%$ of total observations over the period 1980-2004. This clearly shows that tourism mainly relies on an international fragmentation of its production.

[Please insert Table 2 here]

[Please insert Figure 3 here] 
However examining the share of countries and frequency of countries displaying one and only one tourism comparative advantage is not sufficient to assess the real quantitative importance of the IDTP since their trade flows in A and T might be small. In our case, this group of countries was the cause of more than $56 \%$ of the whole sample's tourism exports of A and T and of about $38 \%$ of the whole sample's tourism imports of A and $\mathrm{T}$ over the period studied. All in all its weight in total international tourism trade ${ }^{\mathrm{xxix}}$ was on average the same as its share in the total observations made (about $44 \%$ ). Hence the economic importance of IDTP (in terms of trade) has been equivalent to its frequency (in terms of countries and observed cases). Moreover Figure 4 reveals that this economic importance even rose over time: despite a decline in the 1980s, the weight of IDTP in international tourism trade increased on average by $2.2 \%$ per year over the entire period. (A similar expansion can be observed for the weight of IDTP in total tourism exports and in total tourism imports, as shown in Figures A.1 and A.2 in the appendix, the annual average growth rate being about $2 \%$ in each case $)^{\mathrm{xxx}}$. Partial specialization seems to be a growing phenomenon and appears as an active factor of tourism trade flows' expansion.

\section{[Please insert Figure 4 here]}

\section{IV-2. Analysis of bilateral flows.}

The analysis of comparative advantages and disadvantages a country displays with regard to the rest of the world (i.e. its partners altogether) can provide a useful idea on the nature of its specialization in a sector. But it might also be misleading since the aggregation of bilateral flows can be the source of underestimation or overestimation of the IDTP. Let us consider three countries, $\mathrm{X}, \mathrm{Y}$ and $\mathrm{Z}$, and assume that $\mathrm{X}$ displays a comparative advantage for segment $\mathrm{A}$ with $\mathrm{Y}$ and for $\mathrm{T}$ with $\mathrm{Z}$, but a comparative disadvantage for $\mathrm{T}$ 
with Y and for A with Z. This country is clearly involved in an IDTP with the two other countries. But if for each segment, its comparative advantage is larger than its comparative disadvantage, then the geographical aggregation of flows by segment shows an integrated specialization of country $\mathrm{X}$ with regard to the rest of the world (structural surpluses for A and $\mathrm{T}$ with regard to countries $\mathrm{Y}$ and $\mathrm{Z}$ altogether). In this case, an analysis at the aggregated level fails to detect any IDTP.

Let us now assume that country $\mathrm{X}$ displays a comparative advantage for both segments A and T with Y, but a comparative disadvantage for both segments with Z. Hence country X's specialization is exclusively integrated, whatever the partner considered. But if for one segment, its comparative advantage is larger than its comparative disadvantage, and the opposite is true with the other segment, then the geographical aggregation of flows by segment leads to the conclusion of a partial specialization for X. The IDTP appears here as a pure statistical artifact resulting from an insufficient disaggregation of data.

Therefore the most relevant level of geographical aggregation to study the IDTP seems to be at the bilateral level: the analysis of a country's comparative advantages should be carried out by considering its trade flows with each of its partners separately. Unfortunately, working with data on trade in tourism services is not easy. Bilateral tourism trade flows are rather scarce and they are not harmonized. Additionally, they are not available for the whole initial sample of 38 countries. The only available data are provided by the OECD data set on cross-border trade in services $(2003,2006)$ which covers 22 OECD-countries and 55 partner countries for the period 1999-2003. We have to deal with these issues to provide an original study based on relevant bilateral data of 15 countries of 
the pre-2004 Enlargement European Union ${ }^{\mathrm{xxxi}}$. Three reasons led us to choose these countries. First, they form a group with an economic and institutional homogeneity. Second, intra-EU tourism has a large weight in world tourism flows. Third, their bilateral value declarations turned out to be of satisfactory quality, providing us with a sample of harmonized and homogenous data ${ }^{\mathrm{xxxii}}$.

Let us start by determining what kind of specialization an analysis at the aggregated level reveals for the EU-14. The result will allow us to assess the gain of precision obtained by using a bilateral analysis. When A and T's CTB indexes are computed for each country with its 13 partners altogether, the frequency of cases of IDTP observed over the entire period (1999-2003) represents $27.1 \%$, which was the cause of $19.4 \%$ of total intra-EU (14) tourism trade (sum of exports and imports of $\mathrm{A}$ and $\mathrm{T}$ ). Therefore more than a quarter of all pairs of EU-14 countries were involved in a partial specialization, which clearly suggests that a significant IDTP existed in the pre-2004 Enlargement European Union.

Let us now refine this result by computing the annual CTB indexes for segments A and $\mathrm{T}$ of each country with each of its 13 partners separately. Then the frequency of cases of IDTP observed comes to an average of $34.2 \%$ over the period studied ${ }^{\mathrm{xx} x i i}$, accounting for $35.3 \%$ of total EU-14 tourism flows (sum of exports and imports). An analysis of comparative advantages at the bilateral level thus increases the weight of partial specialization in total observed cases by eight points as compared to an aggregated level analysis, and by much more when considering its weight in total trade. This reinforces the conclusion that the splitting-up of tourism's value-added chain was a large and widespread phenomenon in the pre-2004 Enlargement European Union, with the IDTP representing more than a third of total intra-EU (14) tourism trade. 
But it may also be interesting to examine if all countries are concerned by this EUlevel IDTP. The first column of Table 3 (Table 3A) ranks the 14 countries according to the frequency of reciprocal comparative advantages cases observed in all their bilateral relationships over the period studied. The second column (Table 3B) ranks them according to the average share of IDTP in each country's total tourism trade (the sum of exports and imports of $\mathrm{A}$ and $\mathrm{T})$

[Please insert Table 3 here]

Several conclusions can be drawn from this table.

- First, all EU countries are significantly involved in the IDTP, with the noteworthy exceptions of Spain and Greece. These two Mediterranean countries display a highly prevalent (positive) integrated specialization with their partners which is the cause of most of their tourism trade flows. But all other EU countries have fragmented their tourism product system in a significant way: the IDTP never accounts for less than a quarter of bilateral relationships and trade. Its share often exceeds $40 \%$ either in terms of partners and frequency (United Kingdom, Sweden) or in terms of total tourism trade (Ireland, Portugal, France, Finland), or both (Italy, the Netherlands, Denmark). Partial specialization even dominates tourism trade in the Netherlands (57.0\%), Italy (69.3\%) and especially Ireland (80.4\%).

- Second, for most countries, the weight of IDTP in total trade is generally larger than its frequency. This means that IDTP is a powerful generator of tourism trade. Ireland offers a dramatic case: while accounting for only one third of this country's 
bilateral relationships (34.4\%), involvement in a partial specialization gave rise to $80 \%$ of its total tourism trade. Exceptions are Spain, Sweden, Denmark and the UK. For the latter, IDTP was predominant in its bilateral relationships (51.6\%), but did not even cause two-fifths $(38.1 \%)$ of its tourism trade.

\section{CONCLUSIONS}

The importance of international fragmentation of production as one of the manifestations for the increased globalization of the world economy has been the focus of a growing economic literature in the last decade. This paper has examined fragmentation and globalization in the case of the tourism industry. In this context, the IDTP phenomenon refers to the breaking-up of tourism production processes into various components, which can be produced in different locations around the globe. Our paper provides theoretical and empirical evidence of such a phenomenon. We started by developing a simple Ricardian model with two countries, two final goods and three intermediate goods (used in the production of the final tourism good). This theoretical framework provides a rationale for the IDTP and some specific related increasing phenomenon, such as cabotage, offshore outsourcing in tourism, TOs' new practices, etc. It refines the explanation of countries' tourism specialization patterns.

This splitting-up of the value added chain in tourism allows for a more in-depth specialization: different stages of tourism production correspond to different production functions or different factor endowments so that a country may have a tourism comparative advantage in one stage of production and comparative disadvantages in other stages. 
Extending the concept of tourism specialisation beyond final products to the realm of component activities thus opens up new opportunities for international tourism trade. It does so by rewarding those countries that are relatively better at producing some fragment of the tourism product system. Giving up the most disadvantaged tourism activities and concentrating on doing what can be done better or best improves the utilization of resources and thus raises efficiency and welfare for both origin and host countries.

From an empirical point of view, our findings support the IDTP phenomenon for a large sample of 38 countries. The measurement of comparative advantages for two segments of the value added chain in tourism shows that tourism production is globally fragmented, and that the scale of such fragmented production is quite substantial for a large number of these countries. Furthermore, our long-term dataset (1980-2004) indicates that tourism specialization is a dynamic process. Looking more specifically at the case of IDTP at the bilateral level for the 15 countries of the pre-2004 Enlargement European Union, we found evidence that an international fragmentation specialization is increasingly taking place within them, and that fragmentation in tourism production appears as an active factor of tourism trade flows' expansion. 


\section{REFERENCES}

Algieri B. (2006). "International tourism specialization of small countries.” International Journal of Tourism Research, 8: 1-12.

Arndt S.W. (1997a). "Globalization and the open economy." North American Journal of Economics and Finance, 8: 71-79.

Arndt S.W. (1997b). “Globalization and the gains from trade." In Trade, growth, and economic policies in open economies, edited by K. J. Koch and K. Jaeger. New York: Springer-Verlag.

Arndt S.W. and H. Kierzkowski, eds. (2001). Fragmentation: New Production and Trade Patterns in the World Economy. Oxford: Oxford University Press.

Balassa, B. (1965). “Trade Liberalization and 'Revealed' Comparative Advantage.” The Manchester School of Economic and Social Studies. 32: 99-123.

Berthélemy J.-C., Bonnefoy F. and Lassudrie-Duchêne B. (1986). Importation et Production Nationale. Paris: Economica.

Burkart A.J. and S. Medlik (1974). Tourism: Past Present and Future. London: Heinemann.

Chen H., M. Kondratowicz and K.M. Yi (2005). "Vertical specialization and three facts about U.S. international trade." North American Journal of Economics and Finance. 16: $35-59$.

Deardorff A. (2001). "Fragmentation in simple trade models." North American Journal of Economics and Finance. 12: 121-137.

Deardorff A. (2005). "Ricardian Comparative Advantage with Intermediate Inputs." North American Journal of Economics and Finance. 16: 11-34. 
Dixit A. K. and G. M. Grossman (1982). "Trade and protection with multistage production." Review of Economic Studies. 59: 583-594.

Dornbusch R., S. Fisher and P.A. Samuelson (1977). “Comparative Advantage, Trade and Payments in a Ricardian Model with a Continuum of Goods." American Economic Review. 67: 823-839.

Dunning J.H. and M. McQueen (1981). “The Eclectic Theory of International Production: A Case study of the International Hotel Industry." Managerial and Decision Economics. 2 (2): 197-210.

Endo K. (2006). "Foreign Direct Investment in Tourism: Flows and Volumes.” Tourism Management. 27(4): 600-614.

Ethier W.J. (1982.). "National and International Returns to Scale in the Modern Theory of." American Economic Review. 72(3): 389-405.

Eurostat/OECD/WTO/UN (2001). Tourism Satellite Account: Recommended Methodological Framework. Luxembourg, Paris, Madrid, New York.

Fontagné L. (1991). Biens Intermédiaires et Division Internationale du Travail. Paris: Economica.

Forrester Research (2002). “3.3 Million US services jobs to go offshore.” TechStrategy Brief, by McCarthy, John. and al., November.

Geyikdagi N.V. (1995). "Investment in tourism development and the demand for travel." Rivista Internazionale di Scienze Economiche e Commerciali. 42(5): 391-403.

Gilbert D. C. (1990). “Conceptual issues in the meaning of tourism.” In Progess in Tourism, Recreation and Hospitality Management, edited by Cooper C.P. London: Belhaven Press. Pp 4-27.

Grossman G. and E. Helpman (2002a). "Integration versus outsourcing in industry equilibrium.” Quarterly Journal of Economics. 117: 85-120. 
Grossman G. and E. Helpman (2002b). "Outsourcing versus FDI in industry equilibrium.” Journal of the European Economic Association. 1: 317-327.

Grossman G. and E. Helpman (2005). "Outsourcing in a global economy.” Review of Economic Studies. 72: 135-159.

Haberler G. (1936). Theory of International Trade. London: William Hodge \& Co.

Helpman E. and P.R. Krugman (1985). Market Structure and Foreign Trade. Cambridge, MA: MIT Press.

Hummels D., J. Ishii and K-M. Yi (2001). "The nature and growth of vertical specialization in world trade." Journal of International Economics. 54: 75-96.

Hummels D., D. Rapoport and K-M. Yi (1998). "Vertical specialization and the changing nature of world trade." Federal Reserve Bank of New York. Economic Policy Review. 4(2): 79-99.

International Monetary Fund (2005). Travel-Implications of the Technical Sub-Group Position for Balance Of Payments Statistics. BOPCOM-05/16. Eighteenth Meeting of the IMF Committee on Balance of Payments Statistics Washington, D.C. June 27-July. 1:2005.

Jenen C. and J. Zhang (2006). "Comparative Advantage Explaining Tourism Flows." Annals of Tourism Research. 34 (1): 223-243.

Jones R.W. (1961). “Comparative Advantage and the Theory of Tariffs: a Multi-Country, Multi-Commodity Model.” Review of Economic Studies. 28: 161-175.

Jones R.W. (2000). Globalization and the Theory of Input Trade. Cambridge: MIT Press. Jones R.W. and H. Kierzkowski (2005). "International Fragmentation and the New Economic Geography." North American Journal of Economics and Finance.16: 1-10. Katz L.F. and K.M. Murphy (1992). “Changes in Relative Wages, 1963-1987: Supply and Demand Factors." Quarterly Journal of Economics. 107: 35-78. 
Koutoulas D. (2006). "The market influence of tour operators on the hospitality industry." In Corporate Rivalry and Market Power: Competition Issues in the Tourism Industry edited by Papatheodorou A., I.B. Tauris edition: 94-123.

Krugman P.R. (1995). “Growing World Trade: Causes and Consequences.” Brooking Papers on Economic Activity. 1: 327-62.

Lafay G. (1992). “The Measurement of Revealed Comparative Advantages.” In International Trade Modelling, edited by M.G. Dagenais and P-A. Muet. London: Chapman \& Hall.

Lassudrie-Duchêne B. (1982). "Décomposition internationale des processus productifs et autonomie de décisions." In Internationalisation et Autonomie de Décision, edited by H. Bourguinat. Paris: Economica. Pp 45-66.

Lassudrie-Duchêne B. (1985). "L'échange international avec segmentation des produits : une approche par la théorie classique des coûts comparés." In Le Protectionnisme:Croissance, Limites, Voies Alternatives, edited by Lassudrie-Duchêne B. et J-L. Reiffers. Paris: Economica.

Leamer E.E. (1996). “The Effects of Trade in Services, Technology Transfer, and Delocalization on Local and Global Income Inequality." Asia-Pacific Review. 2: 44-60. Markusen J.R. (2005). Modeling the Offshoring of White-Collar Services: From Comparative Advantage to the New Theories of Trade and FDI. Paper prepared for the Brookings Forum "Offshoring White-Collar Work: The Issues and Implications”. May 12-13.

Nowak J-J and M. Sahli (2007). “Coastal Tourism and 'Dutch disease' in a Small Island Economy." Tourism Economics. 13(1): 49-65.

OECD (2003, 2006). OECD Statistics on International Trade in Services; detailed tables by service category. Paris. 
Organization for Economic Co-operation and Development (OECD) (2005). OECD

Information Technology Outlook 2004. Chapter 2, Globalisation of the ICT sectors and International sourcing of ICT-enabled services. Paris: OECD.

Peterson J.C. (1988). "Export shares and revealed comparative advantage: a study of international travel." Applied Economics. 20: 351-65.

Prideaux B. (2000). "The role of the transport system in destination development." Tourism Management. 21: 53-63.

Sahli M. (1999). Tourisme et Spécialisation Internationale. Unpublished PhD thesis. France: Universite Paris I Panthéon-Sorbonne.

Sahli M. (2006). “Tourism Specialization: a comparison of 19 OECD destinations.” In International Handbook of Economics of Tourism, edited by Dwyer L and P. Forsyth. Edwar Elgar Edition. Pp 705-732.

Sanyal K. K. (1983). "Vertical specialization in a Ricardian model with a continuum of stages of production." Economica. 50: 71-78.

Sanyal K.K. and R.W. Jones (1982). "The Theory of Trade in Middle Products.” American Economic Review. 72: 16-31.

Sinclair T. and M. Stabler (1997). The Economics of Tourism. London: Routledge.

Stern R. M (2005). The place of services in the world economy. RSIE Discussion Papers. N0. 530: February.

United Nations Conference on Trade and Development (UNCTAD) (2004). "The shift towards services. Chapter IV, The offshoring of corporate service functions: The next global shift." World Investment Report 2004. Geneva: UNCTAD.

Venables A. (1999). "Fragmentation and multinational production". European Economic Review. 43: 935-945. 
World Trade Organization (WTO) (2005). World Trade Report “Offshoring services: recents development and prospects". Geneva: 265-94.

Yeats A. J. (2001). "Just how big is global production sharing?" In Fragmentation: New Production Patterns in the World Economy, edited by S.W. Arndt \& H. Kierzkowski. Oxford: Oxford University Press.

Yi K.-M. (2003). “Can vertical specialization explain the growth of world trade?" Journal of Political Economy. 111: 52-102. 


\section{Figure 1}

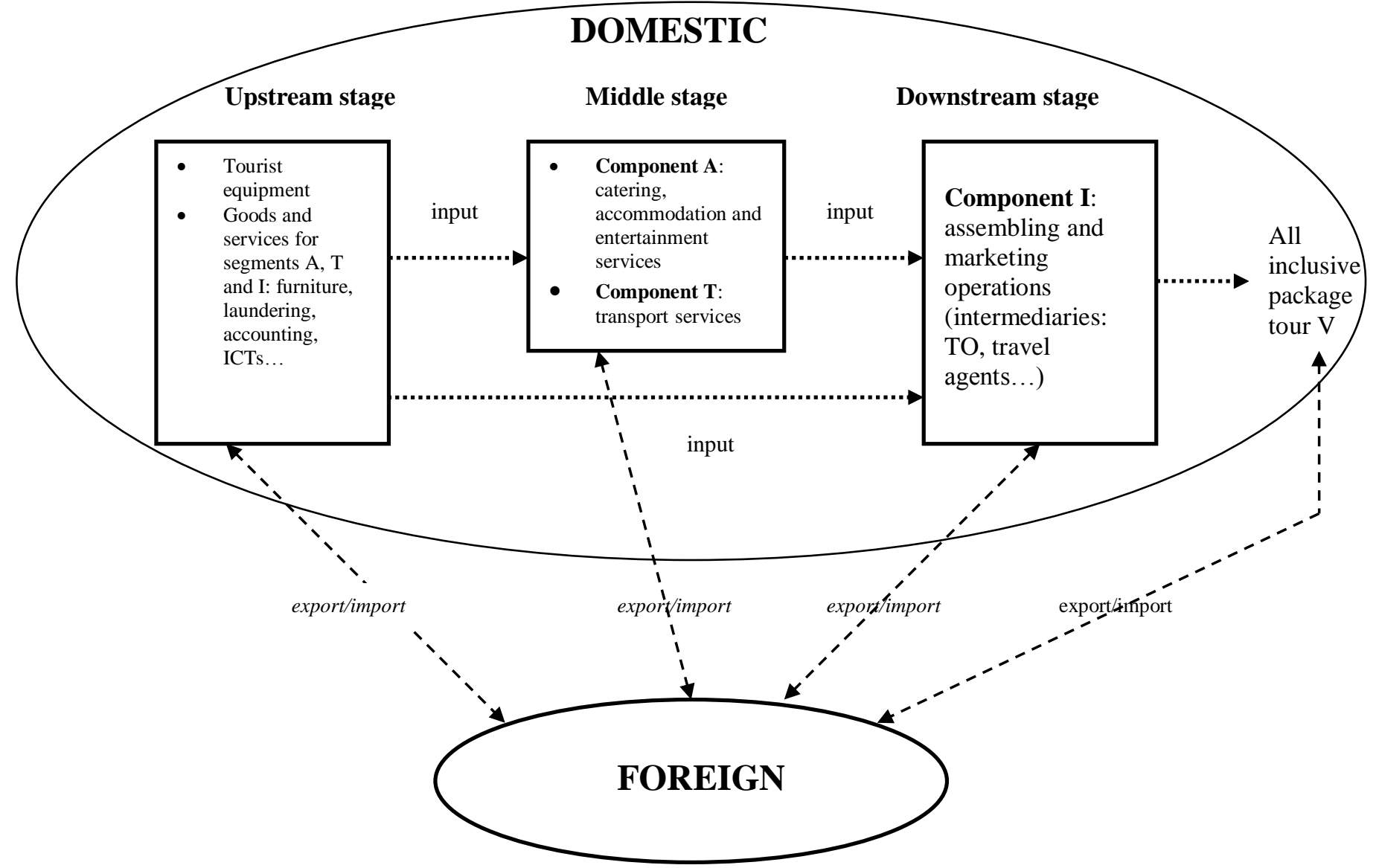




\section{Figure 2}

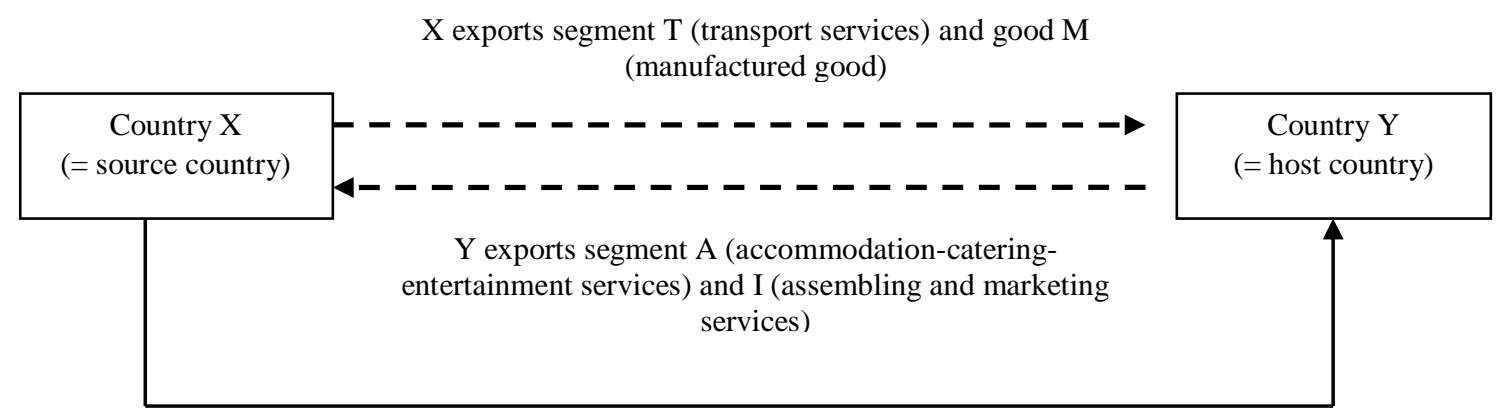

International tourism flows 
Table 1A - Evolution of tourism segment A's comparative advantage by country (1980-2004)

\begin{tabular}{|c|c|c|c|c|c|c|c|c|}
\hline & $80-82$ & $83-85$ & $86-88$ & $89-91$ & $92-94$ & $95-97$ & $98-2000$ & 2001-04 \\
\hline United States & + & + & + & + & + & + & + & + \\
\hline Canada & - & - & - & - & -- & - & - & - \\
\hline France & + & + & + & + & + & + & + & + \\
\hline BLEU & -- & - & -- & -- & -- & -- & -- & -- \\
\hline Germany & -- & -- & -- & -- & -- & -- & -- & -- \\
\hline Italy & ++ & ++ & + & + & - & + & + & + \\
\hline Netherlands & -- & -- & -- & -- & -- & -- & -- & -- \\
\hline United Kingdom & - & - & - & - & - & - & -- & -- \\
\hline Ireland & + & + & - & - & - & -- & -- & --- \\
\hline Denmark & - & - & -- & -- & -- & -- & -- & -- \\
\hline Finland & - & - & -- & -- & -- & -- & -- & - \\
\hline Norway & -- & --- & --- & --- & --- & --- & --- & --- \\
\hline Sweden & -- & -- & -- & -- & -- & -- & --- & -- \\
\hline Iceland & -- & -- & --- & --- & --- & --- & --- & --- \\
\hline Switzerland & + & + & + & + & + & - & - & - \\
\hline Spain & +++ & +++ & +++ & +++ & +++ & +++ & +++ & +++ \\
\hline Greece & +++ & ++ & ++ & ++ & ++ & ++ & +++ & +++ \\
\hline Israel & + & ++ & + & - & + & + & + & - \\
\hline Cyprus & ++++ & +++++ & +++++ & +++++ & +++++ & +++++ & +++++ & ++++ \\
\hline Malta & +++++ & ++++ & +++++ & +++++ & +++++ & +++++ & +++++ & ++++ \\
\hline Japan & - & - & - & - & - & - & - & - \\
\hline Australia & - & - & - & - & + & + & + & + \\
\hline South Africa & + & + & - & + & - & + & + & + \\
\hline Mexico & - & - & - & - & + & + & + & + \\
\hline Brazil & - & - & - & - & - & - & - & - \\
\hline Chile & - & -- & -- & - & + & + & - & - \\
\hline Bahamas & +++++ & +++++ & +++++ & +++++ & +++++ & +++++ & +++++ & +++++ \\
\hline Panama & ++ & ++ & + & + & ++ & ++ & ++ & ++ \\
\hline Morocco & ++ & +++ & +++ & +++ & +++ & +++ & +++ & ++++ \\
\hline Tunisia & ++++ & ++++ & ++++ & ++++ & ++++ & ++++ & ++++ & ++++ \\
\hline Egypt & ++ & + & ++ & +++ & ++ & +++ & +++ & +++ \\
\hline Seychelles & +++++ & +++++ & +++++ & +++++ & +++++ & +++++ & +++++ & +++++ \\
\hline Madagascar & - & - & - & - & - & - & - & - \\
\hline Senegal & ++ & ++ & ++ & ++ & ++ & ++ & ++ & +++ \\
\hline South Korea & - & + & + & + & - & - & - & -- \\
\hline Malaysia & -- & -- & --- & - & + & + & + & ++ \\
\hline Thailand & ++ & ++ & +++ & +++ & ++ & ++ & ++ & ++ \\
\hline Mainland China & + & + & + & + & + & + & - & + \\
\hline $\begin{array}{l}\text { Legend : average } \\
\text { value of } C T B \text { index }\end{array}$ & $\begin{array}{r}+ \\
++ \\
+++ \\
++++ \\
+++++\end{array}$ & $\begin{array}{r}\text { Bet } \\
\text { Bet } \\
\text { Bet } \\
\text { Betv } \\
\quad N\end{array}$ & $\begin{array}{l}\text { een } 0 \text { a } \\
\text { een } 10 \text { a } \\
\text { een } 25 a \\
\text { en } 50 \text { a } \\
\text { re than }\end{array}$ & $\begin{array}{l}10 \\
d 25 \\
d 50 \\
100 \\
y 0\end{array}$ & $\begin{array}{r}- \\
-- \\
--- \\
--- \\
----\end{array}$ & $\begin{array}{l}\text { Bet } \\
\text { Betv } \\
\text { Betv } \\
\text { Betw }\end{array}$ & $\begin{array}{l}\text { ween }-10 \\
\text { een }-25 \\
\text { een }-50 \\
\text { een }-100 \\
\text { ess than - }\end{array}$ & $\begin{array}{l}\text { and } 0 \\
\text { nd }-10 \\
\text { nd }-25 \\
\text { and }-50 \\
100\end{array}$ \\
\hline
\end{tabular}

Source: CHELEM database of CEPII (2006), authors' calculations 
Table 1B - Evolution of tourism segment T's comparative advantage by country (1980-2004)

\begin{tabular}{|c|c|c|c|c|c|c|c|c|}
\hline & $80-82$ & $83-85$ & $86-88$ & $89-91$ & $92-94$ & $95-97$ & $98-2000$ & 2001-04 \\
\hline United States & - & - & + & - & - & - & - & - \\
\hline Canada & - & - & - & - & - & - & - & - \\
\hline France & - & - & - & - & - & - & - & - \\
\hline BLEU & - & - & - & - & - & - & - & - \\
\hline Germany & - & - & - & - & - & - & - & - \\
\hline Italy & - & - & - & - & - & - & - & - \\
\hline Netherlands & - & -- & - & - & - & + & + & - \\
\hline United Kingdom & - & - & - & - & - & - & - & - \\
\hline Ireland & - & -- & -- & -- & -- & -- & --- & -- \\
\hline Denmark & - & - & - & -- & -- & -- & -- & -- \\
\hline Finland & - & - & - & - & - & - & -- & -- \\
\hline Norway & - & -- & + & - & - & + & - & -- \\
\hline Sweden & + & + & - & - & - & - & - & - \\
\hline Iceland & -- & -- & - & - & - & - & - & - \\
\hline Switzerland & - & - & - & - & - & - & - & - \\
\hline Spain & + & + & + & + & - & - & - & - \\
\hline Greece & + & - & - & - & - & - & ++ & +++ \\
\hline Israel & - & - & -- & -- & -- & -- & -- & -- \\
\hline Cyprus & --- & --- & --- & --- & --- & --- & --- & --- \\
\hline Malta & ---- & --- & --- & --- & --- & -- & -- & -- \\
\hline Japan & - & - & - & - & - & - & - & - \\
\hline Australia & - & - & - & - & - & - & - & - \\
\hline South Africa & -- & -- & -- & -- & -- & -- & -- & -- \\
\hline Mexico & - & - & - & - & - & - & - & - \\
\hline Brazil & - & - & - & - & - & - & - & - \\
\hline Chile & -- & -- & -- & -- & -- & - & - & -- \\
\hline Bahamas & --- & --- & ---- & --- & --- & --- & --- & --- \\
\hline Panama & - & +++ & + & + & -- & - & +++ & +++ \\
\hline Morocco & -- & -- & - & -- & - & - & - & - \\
\hline Tunisia & - & - & - & - & + & + & - & - \\
\hline Egypt & +++ & +++ & +++ & +++ & +++ & ++ & + & + \\
\hline Seychelles & ++ & ++ & --- & ++ & ++++ & ++++ & ++++ & ++ \\
\hline Madagascar & -- & -- & --- & -- & --- & --- & --- & --- \\
\hline Senegal & --- & --- & --- & --- & --- & --- & --- & --- \\
\hline South Korea & + & + & - & - & - & - & - & - \\
\hline Malaysia & --- & --- & --- & --- & --- & --- & --- & ---- \\
\hline Thailand & -- & -- & -- & --- & --- & --- & --- & --- \\
\hline Mainland China & - & - & - & - & - & -- & - & - \\
\hline value of $C T B$ index & $\begin{array}{r}+ \\
++ \\
+++ \\
++++ \\
+++++\end{array}$ & $\begin{array}{r}\text { Be } \\
\text { Bet } \\
\text { Bet } \\
\text { Betv } \\
\Lambda\end{array}$ & $\begin{array}{l}\text { een } 0 \text { a } \\
\text { en } 10 \\
\text { en } 25 \\
\text { en } 50 \text { a } \\
\text { re than }\end{array}$ & $\begin{array}{l}10 \\
25 \\
50 \\
100 \\
0\end{array}$ & $\begin{array}{r}- \\
-- \\
--- \\
--- \\
----\end{array}$ & $\begin{array}{r}B e \\
B e t \\
B e t \\
\text { Betv }\end{array}$ & $\begin{array}{l}\text { een }-10 \\
\text { een }-25 \text { a } \\
\text { en }-50 \text { a } \\
\text { en }-100 \text { a } \\
\text { ss than - } 1\end{array}$ & $\begin{array}{l}n d 0 \\
d-10 \\
d-25 \\
n d-50 \\
00\end{array}$ \\
\hline
\end{tabular}


Table 2 - Frequency of IDTP cases observed over 1980-2004

\begin{tabular}{|c|c|c|}
\hline & $\begin{array}{l}\text { Average share of } \\
\text { specialization in }\end{array}$ & \\
\hline \multirow{2}{*}{$\begin{array}{c}\text { Complete } \\
\text { specialization }\end{array}$} & 2 segments & $11,2 \%$ \\
\hline & 0 segment & $44,8 \%$ \\
\hline $\begin{array}{c}\text { Partial } \\
\text { specialization } \\
\text { (IDTP) }\end{array}$ & 1 segment & $46,0 \%$ \\
\hline
\end{tabular}

Source: CHELEM database of CEPII (2006), authors' calculations 
Figure 3 - Evolution of horizontal and vertical specialization (1980-2004)

(Share of observed cases of each kind of specialization in total aggregated flows)

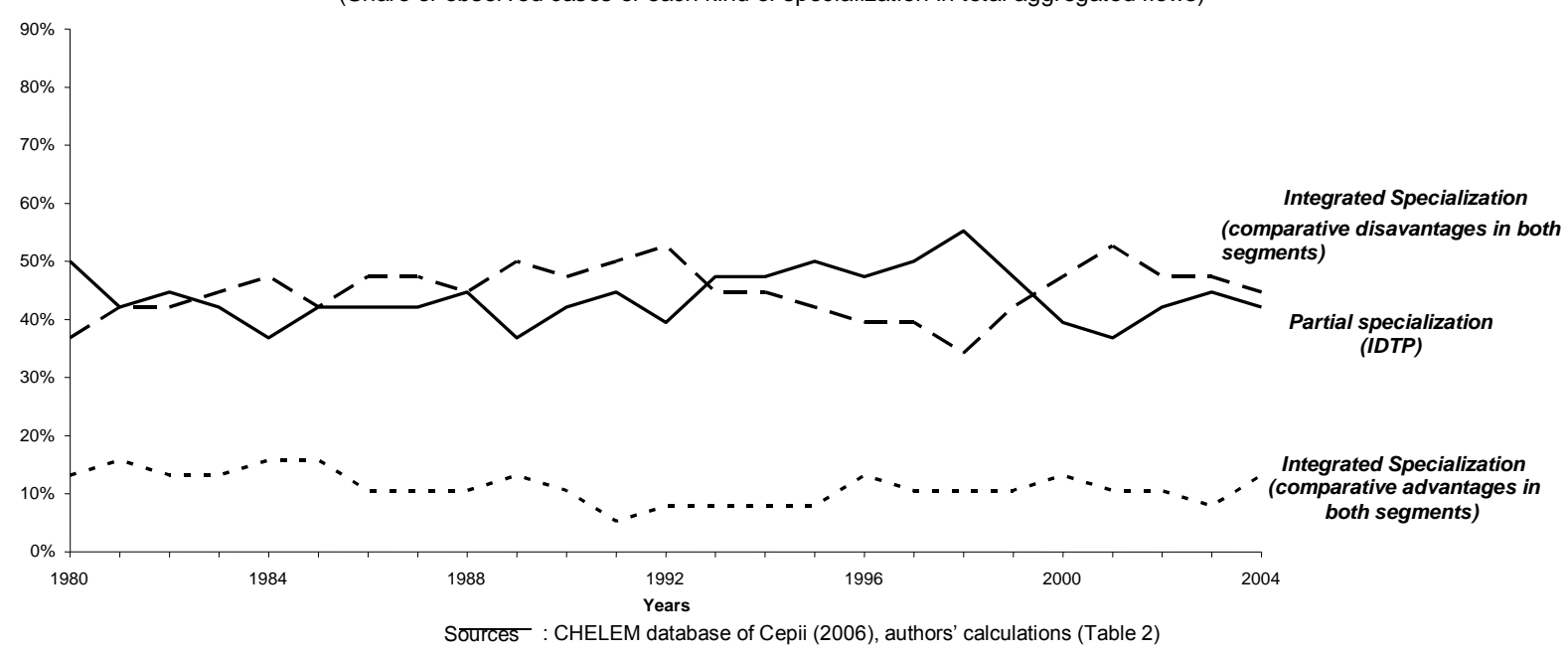


Figure 4 - Share of IDTP in total tourism trade (1980-2004) (exports and imports of A and T by countries involved in IDTP in total exports and imports of $A$ and $T$ )

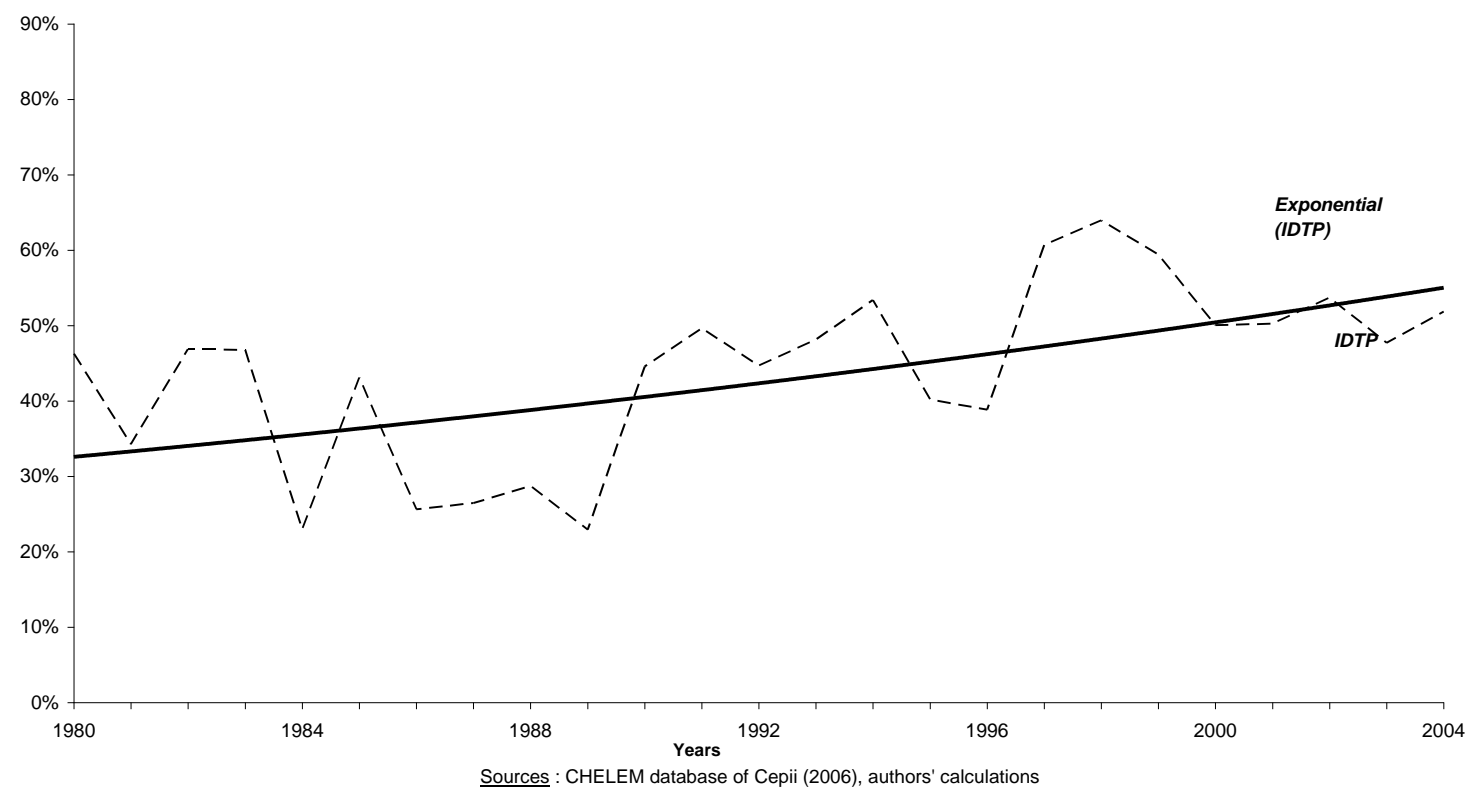


Table 3A - Share of observed IDPT cases in total

Table 3B - Share of trade caused by IDPT in bilateral flows, by country (1999-2003)

total bilateral trade, by country (1999-2003)

\begin{tabular}{|c|c|c|c|}
\hline Italy & $55,4 \%$ & Ireland & $80,4 \%$ \\
\hline United Kingdom & $51,6 \%$ & Italy & $69,3 \%$ \\
\hline Netherlands & $45,8 \%$ & Netherlands & $57,0 \%$ \\
\hline Denmark & $43,6 \%$ & Portugal & $45,1 \%$ \\
\hline Sweden & $42,9 \%$ & France & $42,7 \%$ \\
\hline Portugal & $35,9 \%$ & Denmark & $41,4 \%$ \\
\hline Ireland & $34,4 \%$ & Finland & $41,4 \%$ \\
\hline Finland & $33,3 \%$ & Sweden & $38,4 \%$ \\
\hline France & $31,7 \%$ & United Kingdom & $38,1 \%$ \\
\hline Belgium-Luxembourg & $31,3 \%$ & Belgium-Luxembourg & $35,9 \%$ \\
\hline many & $26,4 \%$ & Germany & $28,9 \%$ \\
\hline Austria & $23,4 \%$ & Austria & $25,6 \%$ \\
\hline Spain & $11,1 \%$ & Greece & $14,8 \%$ \\
\hline Greece & $4,3 \%$ & Spain & $4,5 \%$ \\
\hline
\end{tabular}

Interpretation :

Table 3A: Italy displayed one comparative advantage only with $55.4 \%$ of its bilateral partners on average over 1999 2003.

Table 3B: tourism trade with these partners (sum of exports and imports for A and T) was the cause of $69.3 \%$ of Italy's total tourism trade (with EU 13) over 1999-2003.

Source: OECD database $(2003,2006)$, authors' calculations 


\section{Appendix}

Figure A.1- Share of IDTP in total tourism exports (1980-2004) (exports of A and T by countries involved in IDTP in total exports of $A$ and $T$ )

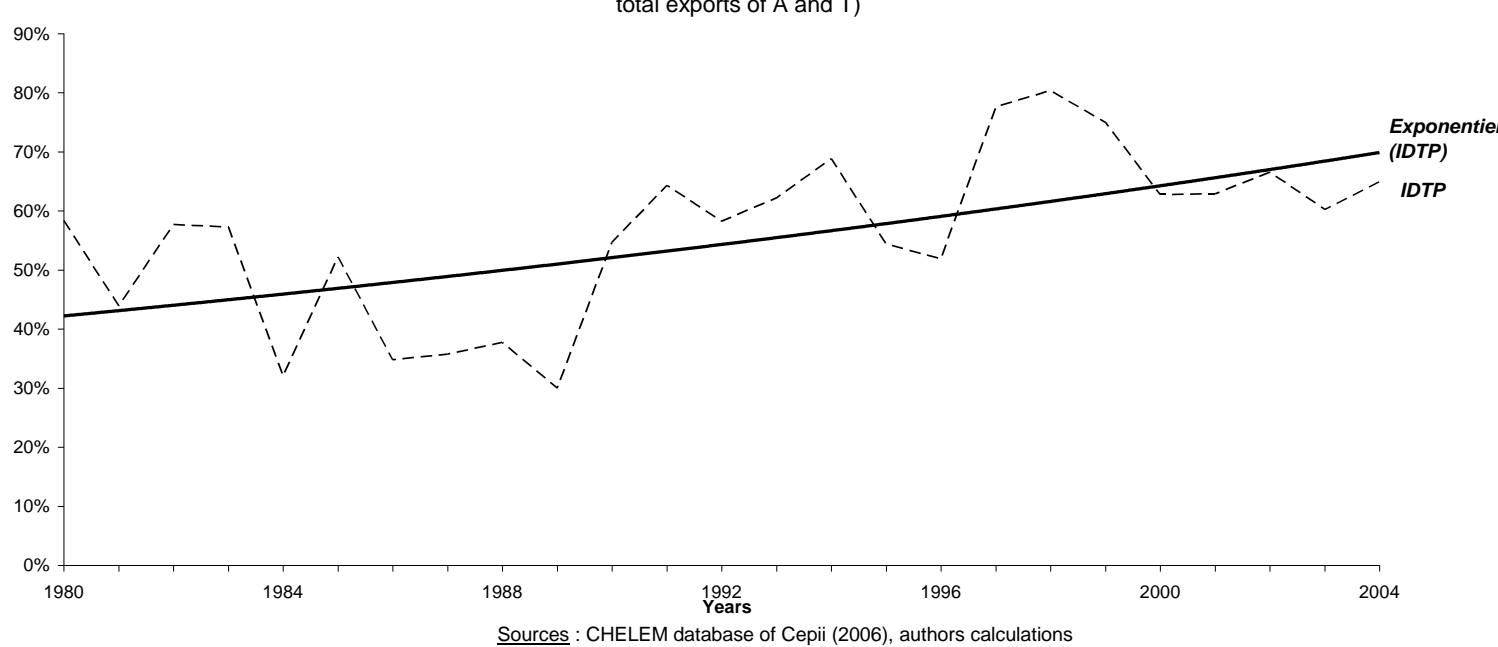

Figure A.2 - Share of IDTP in total tourism imports (1980-2004) (imports of A and T by countries involved in IDTP in total imports of $\mathrm{A}$ and $\mathrm{T}$ )

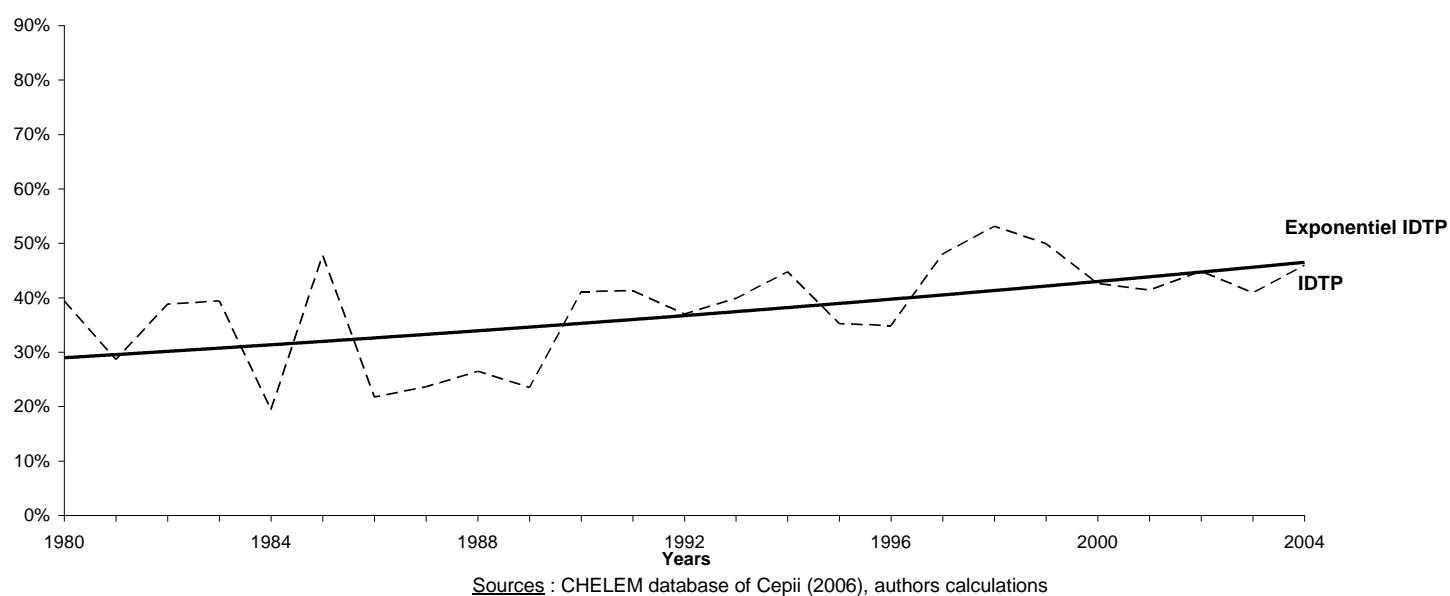


${ }^{\mathrm{i}}$ Or internationally outsourced, internationally segmented. Even if there may be slight differences among all these expressions, we will use them as equivalent from now on, except for vertical specialization (Hummels, Ishii and Yi, 2001) which is a narrower concept. Some cases of vertical specialization in tourism will be highlighted in section II. ii 1) Hotels and similar, 2) second home ownership, 3) restaurants and similar, 4) railway passenger transport services, 5) road passenger transport services, 6) water passenger transport services, 7) air passenger transport services, 8) transport supporting services, 9) transport equipment rental, 10) travel agencies and similar, 11) cultural services, 12) sporting and other recreational services.

iii They further maintain that "It is, therefore, convenient to consider it as a collection of industries..." (Sinclair and Stabler, 1997, p.58).

iv Especially thanks to the development of new ICTs and the emergence of various forms of foreign direct investment in tourism (equity vis-à-vis non equity ownership modes: franchising, joint-venture, management contracts, etc). This point will be detailed in section II.

${ }^{\mathrm{v}}$ Note for example that the popular view that Northern European countries (Germany, UK, the Netherlands, etc) are specialized in transport and tour operating whereas Southern European countries (Spain, Greece, Croatia, etc) are specialized in sand-sun-and-sea activities is in line with this hypothesis.

${ }^{\text {vi }}$ The only exception is Sahli $(1999,2006)$.

${ }^{\text {vii }}$ It seems sensible to put accommodation, catering and entertainment altogether in the same sector, as these services are more likely to be provided within the destination country. This may not be the case for transport and tour operating. 


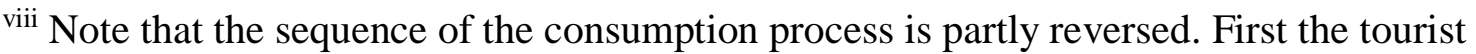
buys the final package tour from the intermediary agent (upstream stage). Then (he/she) needs to be transported to the holiday destination (middle stage) and finally (he/she) consumes the accommodation-catering-entertainment services (downstream stage).

${ }^{\text {ix }}$ For further details, see Endo (2006).

${ }^{\mathrm{x}}$ See Yi (2003) for a more elaborated Ricardian (dynamic) trade model explaining international fragmentation. Yi's simulations show that his model performs especially well in explaining world trade growth from the late 70 s onwards.

${ }^{\mathrm{xi}}$ Adding another segment of goods and services that are used as inputs by sectors $\mathrm{A}, \mathrm{T}$ and I (the above "upstream stage") does not provide any additional insight, except for the narrower concept of vertical specialization. This case will be presented below. ${ }^{\text {xii }}$ In a model of international trade with intermediate inputs, comparative advantages have to be expressed in terms of "labor required per dollar of value added" for the goods considered (Deardorff, 2005). For any sector, this is defined by the ratio of direct unit labor requirement to value added per unit of good produced. As unit value added depends on both intermediate input requirements and prices, then it will be the same in countries having identical prices (free and frictionless trade) and identical intermediate input coefficients. Therefore sectors' unit value added cancel out in the expression of comparative advantages which now reduces to the standard expression involving only direct labor requirements.

xiii In the Ricardian model, this relative wage rate depends on the relative sizes of countries and demand for goods. The exact determination of this rate is of no consequence for our analysis. 
${ }^{\text {xiv }}$ From (2), we get: $a_{L j}^{Y} \cdot\left(e \cdot w^{Y}\right)<a_{L j}^{X} \cdot w^{X}$ for $\mathrm{j}=\mathrm{A}, \mathrm{T}, \mathrm{I}$. The unit labour requirement times the wage rate is the marginal (average) cost of segment $\mathrm{j}$ in local currency, which equals its price (assumption of perfect competition): $a_{L j}^{X} \cdot w^{X}=P_{j}^{X}$ and $a_{L j}^{Y} \cdot w^{Y}=P_{j}^{Y}$ for $\mathrm{j}=\mathrm{A}, \mathrm{T}, \mathrm{I}$. The preceding inequality can thus be expressed as $\left(e \cdot P_{j}^{Y}\right)<P_{j}^{X}$ (both prices are expressed in Domestic's currency), which means that any tourism segment is more expensive to produce in Domestic than in Foreign. On the contrary, the manufactured good $\mathrm{M}$ is cheaper to produce in Domestic than in Foreign:

$a_{L M}^{X} \cdot w^{X}<a_{L M}^{Y} \cdot\left(e \cdot w^{Y}\right) \Rightarrow P_{M}^{X}<e \cdot P_{M}^{Y}$

${ }^{\mathrm{xv}}$ From (3), we get: $a_{L T}^{X} \cdot w^{X}<a_{L T}^{Y} \cdot\left(e \cdot w^{Y}\right)$, which means that unit labour costs for transport services are lower in $\mathrm{X}$ than $\mathrm{Y}$. As unit costs equal prices (perfect competition), we get $P_{T}^{X}<e \cdot P_{T}^{Y}$ : country $\mathrm{X}$ is then more competitive than $\mathrm{Y}$ for transport services. ${ }^{\mathrm{xvi}}$ Since the package tour $\mathrm{V}$ is assembled and marketed by TOs, it will be sold by the country displaying a comparative advantage for segment I, here country $\mathrm{Y}$, to the country displaying a comparative disadvantage for I, here country X.

xvii Note that while tourists from country X still spend their holidays in country Y, they now use their own national carriers to travel from $\mathrm{X}$ to $\mathrm{Y}$, unlike in case 1.

xviii Inward processing imports are defined as intermediate goods imports from a foreign economy for further processing at home, after which the goods are re-exported, usually under tariff exemption.

${ }^{\text {xix }}$ Outward processing exports are defined as intermediate goods exports for further processing in a foreign economy, after which the goods are re-imported, usually under tariff exemption.

${ }^{x x}$ The creation of this single European aviation market in 1993 saw traffic double by 2005 . Competition resulted in industry restructuring and increased competitiveness. The result is 
that Europe's carriers are nowadays among the strongest in the world and European consumers are travelling more than ever.

${ }^{x x i}$ Note that we have here another example of inward processing imports for country Y and outward processing exports for country X.

xxii Lafay (1992) summarizes the results of this methodological study undertaken at the

\section{CEPII.}

${ }^{x x i i i}$ By definition, the sum of this indicator over all sectors is zero. Moreover this indicator is additive: thus the values for products or sectors can be aggregated to any desired level.

${ }^{\text {xxiv }}$ However, to check the robustness of the results and test whether they depend on the choice of the index, some calculations have also been made by using another indicator, that is Balassa's (1965) index of "revealed comparative advantage" (RCA). Despite its shortcomings (e.g. it only takes into account exports), the Balassa index is one of the most widely used indexes of international trade specialisation. It compares the share of sector i's exports in total exports of a country $\mathrm{j}$ to the share of $\mathrm{i}$ 's exports in total exports of a reference group of countries (e.g. OECD):

$$
\mathbf{R C A}_{\mathrm{ij}}^{\mathrm{t}}=\frac{\mathbf{X}_{\mathrm{ij}}^{\mathrm{t}} / \mathbf{X}_{. j}^{\mathrm{t}}}{\mathbf{X}_{\mathrm{i} .}^{\mathrm{t}} / \mathbf{X}_{.}^{\mathrm{t}}}
$$

with $\mathbf{X}_{\mathrm{i} .}^{\mathrm{t}}$ the exports of products belonging to sector $\mathrm{i}$ by the reference group of countries in year $\mathrm{t} ; \mathbf{X}_{. .}^{\mathrm{t}}$ the total exports of the reference group in year $\mathrm{t}$.

A value of $\mathbf{R C A}_{\mathrm{ij}}^{\mathrm{t}}$ above 1 indicates a comparative advantage of country $\mathrm{j}$ for sector $\mathrm{i}$ in year $\mathrm{t}$ whereas a value below 1 indicates a comparative disadvantage.

${ }^{\text {xxvi }}$ Concerning the assembling and marketing operations completed by tour operators or travel agencies (component I), the IMF Balance of Payments Manual (fifth edition) states 
that services of $\mathrm{TO} /$ travel agencies that are residents in the country visited are included in the "Travel" item, but are indistinguishable (Chapter XII, Travel: Paragraph 242). Transactions of commission agents are recorded in the "Other trade-related services" item of the BOP. But the current treatment of statistics does not provide any solution for the case we are interested in, i.e. when the provider of the travel service (segment A, T) and the intermediary (segment I) are not residents of the same economy (for more details, see for example IMF BOPCOM-05/16). Similarly, there is no relevant data on the imported fraction of goods and services which are used as intermediate inputs in tourism, which prevents us from considering outsourcing occurring at the upstream stage of the tourism production process (see figure 1).

${ }^{\text {xxvii }}$ Detailed charts with annual CTB have also been drawn for each country in order to supplement the information given by Tables 1A and 1B. These charts are available from the authors upon request.

xxviii This result is confirmed by Balassa's RCA which gives an average share of $46.2 \%$ for cases of partial specialization. This demonstrates that the IDTP is not a statistical artifact depending on the index used.

xxix This weight is defined as the ratio of the sum of exports and imports of $\mathrm{A}$ and $\mathrm{T}$ by countries involved in the IDTP to the whole sample's sum of exports and imports of A and $\mathrm{T}$.

${ }^{\mathrm{xxx}}$ All annual average growth rates were obtained through a semi-log linear regression over the period 1980-2004.

${ }^{\text {xxxi }}$ Note that in the OECD data set, Belgium and Luxembourg have been regrouped into a single entity.

xxxii In general, the importing and the exporting country do not report the same value for a bilateral trade flow, giving rise to a problem of symmetry and data consistency. In order to 
deal with this problem and select countries reporting the most reliable data, an econometric procedure has been used (for more details on this procedure, see Nowak, Petit and Sahli, 2007). According to this procedure, the 15 countries of the pre-2004 Enlargement European Union display on average consistent reporting values with each other. xxxiii In other terms, $34.2 \%$ of total pairs of countries over the period were made up of countries displaying a comparative advantage with respect to each other. 